\title{
Cancer treatment: the combination of vaccination with other therapies
}

\author{
Mads Hald Andersen • Rikke Bæk Sørensen • \\ David Schrama • Inge Marie Svane · Jürgen C. Becker • \\ Per thor Straten
}

Received: 2 January 2008 / Accepted: 5 February 2008 / Published online: 20 February 2008

(C) The Author(s) 2008

\begin{abstract}
Harnessing of the immune system by the development of 'therapeutic' vaccines, for the battle against cancer has been the focus of tremendous research efforts over the past two decades. As an illustration of the impressive amounts of data gathered over the past years, numerous antigens expressed on the surface of cancer cells, have been characterized. To this end, recent years research has focussed on characterization of antigens that play an important role for the growth and survival of cancer cells. Antiapoptotic molecules like survivin that enhance the survival of cancer cells and facilitate their escape from cytotoxic therapies represent prime vaccination candidates. The characterization of a high number of tumor antigens allow the concurrent or serial immunological targeting of different proteins associated with such cancer traits. Moreover, while vaccination in itself is a promising new approach to fight cancer, the combination with additional therapy could create a number of synergistic effects. Herein we discuss the possibilities and prospects of vaccination when combined with other treatments. In this regard, cell death upon drug exposure may be immunogenic or non-immunogenic depending on the specific chemotherapeutics. Also, chemo-
\end{abstract}

This article is a symposium paper from the conference "Progress in Vaccination against Cancer 2007 (PIVAC 7)", held in Stockholm, Sweden, on 10-11 September 2007.

M. H. Andersen · R. B. Sørensen · I. M. Svane · P. thor Straten ( $\square)$ Department of Hematology, Center for Cancer Immune Therapy (CCIT), Herlev University Hospital, 54P4, Herlev Ringvej 75, 2730 Herlev, Denmark

e-mail: pethst01@heh.regionh.dk

D. Schrama · J. C. Becker

Department of Dermatology, University Hospital of Würzburg, 97080 Würzburg, Germany therapy represents one of several options available for clearance of $\mathrm{CD}^{+}{ }^{+} \mathrm{Foxp}^{+}$regulatory T cells. Moreover, therapies based on monoclonal antibodies may have synergistic potential in combination with vaccination, both when used for targeting of tumor cells and endothelial cells. The efficacy of therapeutic vaccination against cancer will over the next few years be studied in settings taking advantage of strategies in which vaccination is combined with other treatment modalities. These combinations should be based on current knowledge not only regarding the biology of the cancer cell per se, but also considering how treatment may influence the malignant cell population as well as the immune system.

Keywords Vaccination - Conventional treatment . Combination $\cdot$ Cancer $\cdot$ Chemotherapy

\section{Introduction}

The use of cancer vaccines to induce a therapeutic host anti-tumour immune response has huge potential to complement traditional cancer therapies in a non-overlapping way. The prospects of cancer vaccines are to enable re-calibration of the existing host-tumour interaction, tipping the balance from tumour acceptance towards tumour control to the benefit of the patient. Additionally, the highly specific character of the host immune response minimizes the risk for adverse effects associated with most other cancer therapies currently applied. In general, a successful vaccination requires two components: An antigen and an adjuvant. The "antigen" represents the embodiment of the target that should be cleared from the body. The second requirement-the adjuvant-is an amplifier of the response induced by the antigen it self. Due to the phenomenon of 
"immune escape", in which antigen-negative cancer cells may avoid immune recognition, strategies have been developed that conceptually focus on minimizing the risk of immune escape, by specifically targeting proteins that are important for the function, survival and growth of cancer cells $[1,59,65,74]$. Thus, it is well characterized that molecular events-genetic and epi-genetic changes-lead to the general cancer traits; the capacity to uncontrolled growth (abnormal cell cycle regulation), resistance to death (apoptosis resistance), the potential to migrate and grow at distant sites (metastasis), the capacity to induce new blood vessels (attract endothelial cells) [31]. Also mechanisms involved in suppression of the immune system by cancer cells, e.g., secretion of immune-suppressive mediators) are at play during tumor progression [56], and, in addition, drug resistance is a highly relevant phenomenon that is responsible for the failure of chemotherapy to provide curative outcomes in the treatment of disseminated cancers [11]. The proteins or protein patterns responsible for these characteristics of cancer cells represent ideal target structures for therapeutic intervention, including immunological targeting. Importantly, these traits-molecular mechanisms aside-are essential characteristics of all life-threatening cancers, and therapies based on targeting of these characteristics molecularly are therefore broadly applicable to most if not all cancers. Several proteins responsible for or associated with these cancer traits have been characterized, exemplified by cell division (telomerase [74], Cyp1B1 [41], survivin $[4,7,64,73]$ ), resistance to apoptosis (survivin, ML-IAP, Bcl-2, Bcl-X(L), and Mcl-1 [1, 34]), metastatic potential (Heparanase [71]), angiogenesis (survivin, Bcl-2, VEGFR [50]), and drug resistance [43, 44, 82]. Importantly, these proteins are targets for spontaneous immune responses in cancer patients, and peptides derived from the proteins are expressed on the surface of cancer cells in the context of HLA molecules, and thus represent broadly applicable vaccination targets in therapeutic vaccinations against cancer. Moreover, although vaccination against these proteins or groups of proteins is in itself a promising new approach to fight cancer, the combination with additional therapy could create a number of synergistic effects (Fig. 1).

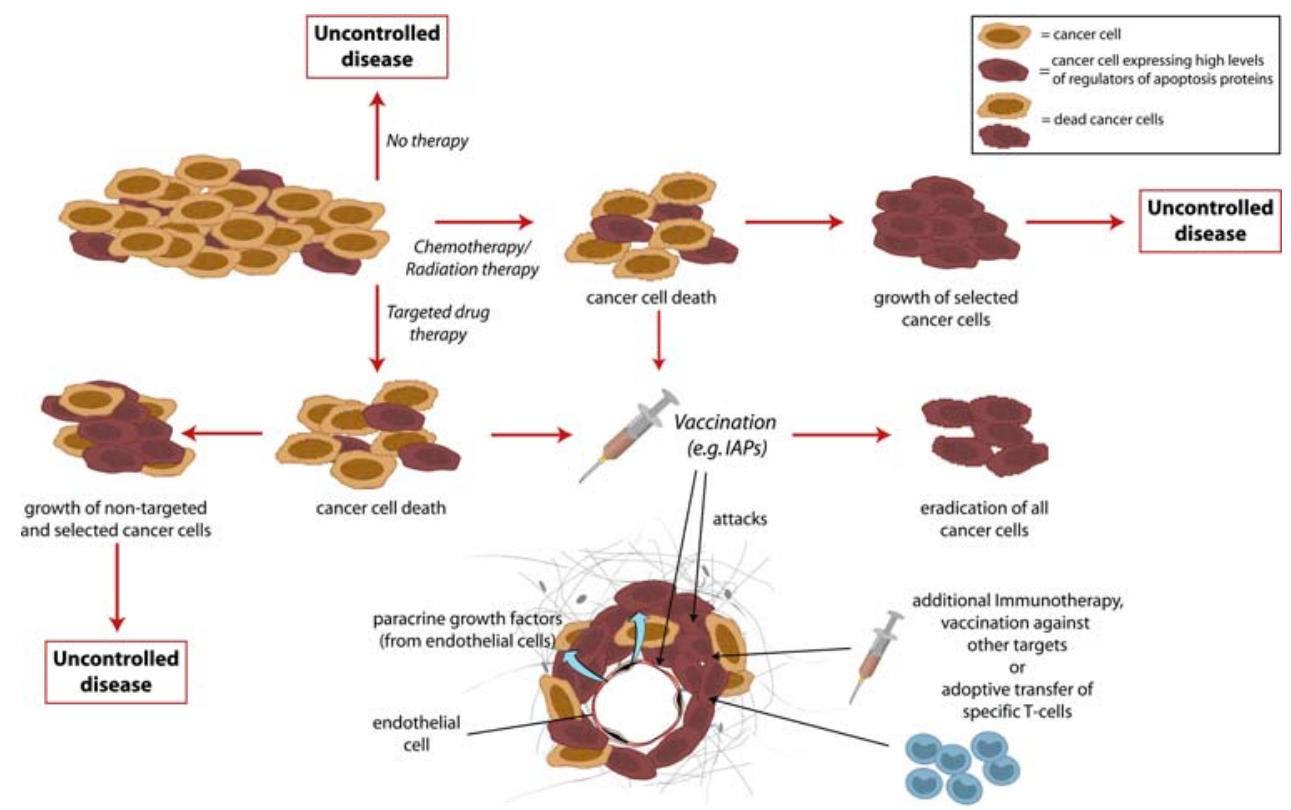

Fig. 1 Conventional chemotherapy effectively kills cancer cells thereby prolonging the life of many cancer patients. However, the development of drug resistance is considered to be the major cause for the failure of chemotherapy in many types of cancer. Tumor cells become resistant to chemotherapy in many ways, one of which is through increased expression of regulators of apoptosis proteins. In a combinational therapeutic setting, conventional therapy would kill the majority of the cancer cells, leaving only resistant cells that express high levels of these proteins. However, such high-expressers would be particularly vulnerable to killing by vaccination induced $\mathrm{T}$ cells. The synergy of these measures would, consequently, give a more effective treatment than either regime alone. Likewise, the resistance of tumor cells to immune cell-mediated apoptosis may contribute to the failure of tumor immunosurveillance, the phenomena of tumor growth despite infiltration by tumor-specific lymphocytes, as well as the failure of tumor vaccines to induce clinical responses despite evidence for priming of effector $\mathrm{T}$ cells. Thus, the combination of vaccination with a strategy using synthetic peptides that compete with caspases for binding to IAPs would be highly synergistic. To maximize the impact of immunotherapy, an exciting strategy would be to co-target biologically connected proteins, for instance survivin, $\mathrm{Bcl}-2$ or $\mathrm{Bcl}-\mathrm{X}(\mathrm{L})$ in a multiepitope setting. An alternative approach would be to combine adoptive transfer of $\mathrm{T}$ cells with vaccination to facilitate expansion and maintenance of T cells in vivo. Finally, vaccination against some proteins addresses both the tumor and the tumor stroma 


\section{Multi-epitope strategies and additional immunotherapy}

As outlined in Fig. 1, combination of vaccination with additional therapy could create synergistic effects. However, some of the fundamental problems associated with therapeutic vaccines still need attention. Thus, in many cases induced biological responses does not correlate with clinical responses, the reasons being largely unknown [55], and probably multifactorial. With current vaccination strategies the induced CTL frequencies are not impressive and although combination with other therapies may help increase these responses, we are still in need of a "gold standard" for therapeutic vaccinations. Thus, research into the generation and phenotype of DCs with optimal capacity to induce full armoured CTLs needs further attention, as does best suited route of administration. Also, the migratory capacity of in vitro generated DCs represent an important parameters [23], as does characterization and examination of adjuvants for in vivo targeting of DCs. Other aspects include homing of $\mathrm{T}$ cells to the tumor site [62], entry into the tumor micro environment [61], and maintenance of function systemically [2, 46, 48, 79], as well as at the tumor site [42, 47]. Moreover, research into the fundamental aspect of timing of vaccination in relation to disease entity and stage requires further study. To this end, it has been suggested that vaccination in the adjuvant setting for prevention of relapse would be optimal but in fact that notion needs verification. The above mentioned short comings of therapeutic vaccinations at its current stage obviously require detailed study of anti-tumor vaccination induced immune resposes, both with regards to the immune system and concerning tumor cell biology [70]. A major step toward the generation of more solid data that can be compared among laboratories, lie in the use of standardized monitoring protocols $[12,36]$. Moreover, the combined use of immunological monitoring with profiling of tumor biopsies [45], may aid the generation of data that set the stage for development of strategies that increase the efficacy of therapeutic vaccination per se.

Many anti-cancer vaccination strategies are already focused on combination with other immunotherapeutic strategies, e.g., the addition of cytokines or immune modulating agents. Hence, numerous investigators have combined vaccines with, e.g., GM-CSF, IL-2, IL-12 or immunomodulatory antibodies such as those against CTLA-4, PD-1, or CD137 [19, 21, 83]. Many agents have not been extensively tested in humans, in particular not in combination with other immune modulators or treatments, e.g., vaccination, in part due to the fact that many agents are not available to the scientific community (please see http:// www.web.ncifcrf.gov/research/brb./workshops.asp).

So far most peptide based vaccination trials have targeted only a single antigen. One concern has been that despite multiple targeting there would be a risk that only a single or a few dominant antigens would elicit reactivity. However, data now suggest that concurrent targeting of multiple antigens is possible, and that the induced responses against individual targets are not influenced negatively due to responses against other antigens [38, 69]. Thus, several clinical trials are ongoing in which multiple peptides from different proteins are targeted (http:// www.clinicaltrial.gov). An exciting strategy would be to co-target biologically connected proteins, e.g., regulators of apoptosis proteins, in a multi-epitope setting. In this regard, as mentioned above a number of different regulators of apoptosis proteins have been described as tumor antigens in a large number of different cancers $[3,5,6,8]$. A combination of these are likely to increase the magnitude and flexibility of the vaccine-induced anti-tumor response and may prevent tumor escape that otherwise would occur through selective loss of single target antigens. Since co-expression of Bcl-2 family proteins is a regular event [68], simultaneous targeting of these proteins may represent a more effective strategy than targeting either molecule alone. Interestingly, the co-expression of survivin and $\mathrm{Bcl}-2$ is strongly associated with poor prognosis in breast cancer [72]. Targeting of both the Bcl-2 protein family and survivin would therefore be particularly attractive since they execute their anti-apoptotic function though different mechanisms [35]. Although regulators of apoptosis proteins are up regulated in almost all cancers there may be significant quantitative differences concerning the amount of each protein in individual patients suffering from the same disease. Previously, we have generated Bcl-2, Survivin and Bcl$\mathrm{X}(\mathrm{L})$ specific cytotoxic T cell clones and examined the killing of a panel of cancer cell lines. Although all cancer cell lines were recognized and lysed by the T-cell clones the most effective lysis varied greatly among the cell lines (Table 1). Thus, some target cells were killed most efficiently by Bcl-2 specific T cells, some by Survivin specific $\mathrm{T}$ cells and some by $\mathrm{Bcl}-\mathrm{X}(\mathrm{L})$ specific $\mathrm{T}$ cells. Although this notion needs to be substantiated in largescale studies in which the clinical and prognostic significance of the different CTL responses is scrutinized, it could point to a scenario in which the targeting of more than one of the targets would be beneficial in a clinical setting.

Concurrent targeting of several proteins with peptides restricted by several HLA molecules would also be expected to lower the risk of immune escape by selection of cancer cells that do not express the one or several of the targeted proteins, however, escape by HLA loss remain a possibility. Several different mechanisms have been described that influence the class I presentation machinery [67], leading to down regulation or loss of HLA class I on the cell surface $[9,53]$. However, allele losses seem far more frequent that complete Class I loss, again underscoring the 
Table 1 Efficacy of tumor cell killing by CTL

\begin{tabular}{llll}
\hline Target cell line/clone & Bcl- $(\mathrm{X}) \mathrm{L}_{173-182}$ & Bcl-2 $_{208-217}$ & Survivin $_{96-104}$ \\
\hline CAMA1 & High & Medium & Low \\
MDA-MB-231 & Low & Medium & High \\
FM3 & Medium & Low & Medium \\
FM55P & ND & High & Low \\
FM72 & ND & Medium & Medium \\
FM81 & ND & High & High \\
\hline
\end{tabular}

Low $<30 \%$ lysis, Medium 30-60\% lysis, High $>60 \%$ lysis

$N D$ not done

potential of concurrent targeting of several or all relevant HLA restriction elements in the patient. Whether such a strategy will lead to more frequent complete loss of HLA expression remains to be seen.

Impressive responses have been achieved in lymphodepleted melanoma patients, by adoptive transfer of in vitro expanded tumor infiltrating lymphocytes (TIL) and high dose IL-2. Transferred T cells expanded in the patients, and clinical response correlate with longevity of the $\mathrm{T}$ cells, suggesting that the proliferative capacity of the $\mathrm{T}$ cells is crucial for clinical relevance [10, 22]. The widespread use of this approach is troublesome since in most cancers TIL is not readily expandable. Several strategies are currently being explored to circumvent this problem, one being to transfect PBMC with tumor specific $\mathrm{T}$ cell receptors prior to transfer to the patient $[49,66]$. Another approach is to use vaccination for induction of antigen specific $\mathrm{T}$ cells, followed by harvest of cells for in vitro expansion and transfer back to the patient upon lymphodepletion [15, 57]. Future trials employing this strategy for targeting tumor antigens will provide important information with regards to the relevance in cancer therapy.

\section{Combination with conventional therapy}

The combination of immunotherapy with chemotherapy has opened new avenues in cancer treatment, and preliminary data suggests a synergistic effect of anti-cancer vaccines and chemotherapy [26]. Only few years ago the concept of combining chemotherapy-one of the side effects of which is suppression of immune function-with active immune therapy, was unheard of. However, data now point in exactly that direction, and since cytotoxic chemotherapy is widely used to treat most malignancies, integrating tumor vaccines with standard chemotherapeutic drugs is highly attractive.

Chemotherapeutic agents can induce a series of cellular responses that impact on tumor cell proliferation and survival. Perhaps the best studied of these cellular responses is apoptosis, a physiological cell death program that controls normal cell numbers during development and disease. It is evident that diverse drugs can kill tumor cells by activation of common apoptotic pathways. Essentially all cytotoxic anticancer drugs, e.g., microtubule binding drugs, DNAdamaging agents, and nucleosides, currently in clinical use, induce apoptosis of malignant cells (Fig. 1).

Drug resistance is the major problem that limits the effectiveness of chemotherapies used in the treatment of cancer. A frustrating property of such acquired resistance is that the tumor not only are become resistant to the specific drug in use, but may also acquire cross-resistance to other drugs with different mechanisms of action [11, 32]. Drug resistance, whether intrinsic or acquired, is believed to cause treatment failure in more than $90 \%$ of patients with metastatic cancer. Cancer-associated defects in apoptosis play a vital role in resistance to chemotherapy and radiotherapy [11]. An important reason for this impaired apoptosis is an over-expression of the anti-apoptotic regulators of apoptosis proteins $[30,68,78]$, e.g., the tumor antigen survivin, or over expression of $\mathrm{ABC}$ transporters [11]. Additionally, drug inactivation by the tumor antigen CYP1B1 may represent a mechanism of resistance, influencing the clinical outcome of chemotherapy [58]. Consequently, immunotherapy targeting these antigens in combination with conventional chemotherapy appears to be particularly appealing. In such a setting, conventional therapy would kill the majority of the cancer cells, leaving only cells that express high levels of antigens, which would be particularly vulnerable to killing by vaccination induced $\mathrm{T}$ cells. Thus, the synergy of these measures could potentially give a more effective treatment than the added effect of either regime alone, thereby strengthening the already described synergistic effect of anti-cancer vaccines and chemotherapy.

As given above, chemotherapy resistant tumor cells may be targeted specifically by vaccination against specific target structure. However, even death it self of the tumor cell may play an important role in explaining how chemotherapy may improve subsequent or even concurrent immune therapy. To this end, it was recently shown that Anthracyclin-treated tumor cells are particularly effective in eliciting an anti-cancer immune responses, since Antracyclins induce the rapid preapoptotic translocation of calreticulin to the cell surface. The surface exposure of calreticulin endows cancer cells with an "eat me signal" to dendritic cells, in turn leading to immunogenic uptake of tumor antigens and activation of a tumor specific $\mathrm{T}$ cell response [52]. These data may prove highly significant for future trials combining immune therapy with chemotherapy, and certainly highlights that there is more to death than dying; that the exact mechanism by which death occurs plays an important role in directing subsequently elicited immunological reactions. Obviously, such data only become impor- 
tant once we consider the notion of combination, since-as we know all too well from the use of these drugs for decades-even the most immunologically relevant ways of dying does not by itself induce curative immunity. However, considering the delicate balance between inflammation and immunity [18], combination of "tailor-selected" chemotherapy and immune modulation, e.g., vaccination may aid tipping the balance. Clinical trials are ongoing that combine vaccination and chemotherapy to accomplish this, however, due to the complexity of these interactions one should expect a bumpy road to improvements of current strategies. As an example of the complexity and plasticity of the mechanisms that governs the exact immunological response, high-mobility group box-1 protein (HMGB-1)an intra-cellular protein involved in inflammation as well as tumorigenesis, is withheld in the cell or liberated to the environment depending on the type of death, and also seems to play opposite roles depending on the presence or absence of other cytokines in the micro-environment [40].

As indicated above novel insight into the immune system has revealed yet another layer of the breathtaking complexity of the system. The idea of suppressor or veto-cells as suppressors of, e.g., anti-tumor responses is certainly not new, and even 25 years ago improved outcome of immune therapy when combined with chemotherapy was suggested to be due to eradication of such suppressor cells [51]. In lack of sufficient evidence for the presence of such cells the concept was abandoned [60]. Recently the concept of suppressor cells_-or regulatory $\mathrm{T}$ cells (Treg)—has gained new life. Based on solid data the existence and relevance of CD4+, CD25+, Foxp3+ positive T cells that are able to suppress cellular immune responses has been firmly validated [80].

Mounting evidence suggests a role of Treg in inhibiting anti-tumor responses, and obviously points to a scenario in which selective clearing or inhibition of Treg could augment the efficacy of vaccination [16]. Regarding the biology of Treg data from murine models have demonstrated the presence of thumus derived Treg (leaves the thymus as Treg; "natural Treg"), and adaptive Treg. These findings have been extrapolated to humans; however, evidence is scarce for the presence of natural Tregs in humans. Moreover, the human life span in combination with the onset of thymic envolution quite early in life, argues against a pivotal role of such cells 20-40 years after termination of thymic output [14]. This holds some implications in the therapy of cancer, in terms of strategies to manipulate these cells, e.g., by selective clearing by chemotherapy. First, it highlights that human Tregs are probably not a special subset of self-specific $\mathrm{T}$ cells that are restricted to regulate auto-immunity, and thus, that Tregs should be viewed as "counter-response" $\mathrm{T}$ cells that only emerge upon long lasting immune responses. Hence, long lasting CTL responses will inevitably lead to a "drag along" Treg response. The implications in the clinic are that clearance of Treg will not elicit long lasting effects since new Tregs will emerge, and, thus, auto-immunity that may develop will vanish as well. In addition clearance of Tregs is likely to be required at an interval that in part depends on the magnitude of the antitumor response. In support of the above notion it has been shown that (some) CD4 $\mathrm{T}$ cells differentiate from naïve through memory to a final FoxP3 state [75]. Also, it has been shown that low dose cyclophosphamide-which has selective cytotoxic effects on Tregs-are capable of clearing Treg, but the effect is short lived [29]. Other drugs may have identical or similar effects, however, for each drug the dosing and schedule needs careful examination to allow for clearing or inhibition of Treg while still maintaining CTL responses. Whether a similar strategy could be used for manipulating other immune cells with suppressive capacity is not yet known [24, 28, 63].

Research into the biology of Tregs is moving forward at high pace. In the next few years we will see new data on the origin, differentiation, function and specificity of these cells, and in parallel data from administration of chemotherapy or antibodies for clearance or inhibition of these cells in the clinic will emerge. Undoubtedly, these data will heavily influence the way we conduct future therapeutic vaccination against cancer, hopefully integrating immune therapy of cancer with conventional treatment strategies to the benefit of the patients.

\section{Combination with treatment regiments targeting apoptosis}

Cytotoxic $\mathrm{T}$ lymphocytes are known to initiate target cell death via two pathways: CD95 ligand and perforin/granzyme (granule-mediated killing). Granzyme B is a major effector molecule of granule-mediated killing that rapidly induces cell death after entering the cytoplasm of the target cell [17]. It has been described that differential expression of apoptosis-related genes might underlie tumor-specific differences in susceptibility to an efferent arm of the immune response, i.e., immunologic cytotoxicity [37]. Hence, the intrinsic resistance of tumor cells to immunologic cytotoxicity might pose a significant limitation to the efficacy of cancer immunotherapy. The resistance of tumor cells to immune cell-mediated apoptosis may contribute to the failure of tumor immunosurveillance, the phenomenon of tumor growth despite infiltration by tumor-specific lymphocytes, as well as the failure of tumor vaccines to induce clinical responses despite evidence for priming of effector $\mathrm{T}$ cells.

In view of this, it is very interesting that strategies aimed at inhibiting the expression or function of anti-apoptotic 
proteins has gained considerable attention [76, 77]. In this regard, it has been described that targeting of the inhibitor of apoptosis protein XIAP by Smac agonists or XIAPsiRNA enhanced the susceptibility of cancer cells for CTLmediated cytotoxicity [37]. Likewise, combining survivin vaccination with a strategy using synthetic peptides that compete with caspases for binding to IAPs could lead to a situation in which the surface presentation of survivin peptides/HLA complexes would remain unchanged but the cancer cells would be more susceptible for killing by survivin specific $\mathrm{T}$ cells.

\section{Monoclonoal antibodies and inhibition of angiogenesis}

Monoclonal antibodies in the treatment of cancer have emerged-after decades in the dark-as very effective drugs. Several mechanisms are involved depending on the antibody as well as the target antigen. Among the immunological mechanisms, antibody dependent cell cytotoxicity and complement-associated mechanisms are at play. Probably the relevance of adaptive immunity depends on the biological mechanisms induced by the antibody. As already discussed in relation to chemotherapy, the type of death may play a role, however, FC part of the antibody may also direct the target protein to processing and presentation to $\mathrm{T}$ cells.

Angiogenesis, the development of new blood vessels by sprouting of the existing vasculature, occurs in cancer but in only a limited range of healthy adult tissues such as the ovary and endometrium during the menstrual cycle or as part of the process of wound healing. Anti-angiogenic therapy utilizes the fact that all tumors beyond a minimal size depend on neo-angiogenesis [33]. Since anti-angiogenic therapy targets the tumor vasculature and prevents tumor growth beyond a certain size, whereas tumor immunotherapy targets the tumor cells, combination of anti-angiogenic therapy and tumor immunotherapy could be highly synergistic. Vascular endothelial growth factor (VEGF) represents one of the most specific and critical regulators of angiogenesis by regulating endothelial proliferation, permeability, and survival. The FDA approval in 2004 of Bevacizumab (Avastin) for the treatment of metastatic colon cancer certainly underscores the relevance of targeting angiogenesis, and several monoclonal $\mathrm{Ab}$ are now approved as anti-angiogenic therapeutics yet for few indications, but numerous phase II and III trials are ongoing [25]. Considering potential benefits of combining Avastin with vaccination, circulating VEGF seem to be correlated to immune suppression $[27,39]$, suggesting that vaccination subsequent to or concurrently with Bevacizumab may improve the efficacy of vaccination.

It has been demonstrated that active immunotherapy targeting endothelial products like vascular endothelial growth factor receptor (VEGFR)-2 protein could inhibit tumor progression [84]. Likewise, it was recently described that tumor growth could be inhibited in mice after vaccination with peptides derived from (VEGFR)-1. This was associated with significant suppression of tumor-induced angiogenesis without showing apparent adverse effects [84]. In addition, survivin, Bcl-2 or Mcl-1 are expressed at high levels in endothelial cells during tumor-angiogenesis [20]. Thus, the targeting of survivin, Bcl-2 or Mcl-1 in a vaccination setting might not only strike the tumor cells, but in addition targets the tumor stroma, due to the fact that these proteins are highly expressed in endothelial cells during tumor-angiogenesis. Hence, the eradication of lung tumor metastases in mice by vaccination induced, survivinspecific $\mathrm{T}$ cells was achieved by joint suppression of angiogenesis in the tumor neovasculature and induction of tumor cell apoptosis [81, 84]. Importantly, the suppression of angiogenesis induced by the vaccine did not impair wound healing or fertility of treated mice. Inhibition of angiogenesis by active immunotherapy offers two attractive features: (1) vaccination against survivin implies the concurrent targeting of angiogenesis and cancer cells and (2) due to the genetically stable nature and limited proliferative capacity of endothelial cells compared to cancer cells, the risk of HLA-loss, antigen-loss, or antigen processing-loss is exceedingly low, if relevant at all. A primary concern of immunizing against angiogenesis-associated products is interference with normal angiogenesis, especially if the effect is sustained. So far no vaccination-associated toxicity was observed when late stage melanoma patients were vaccinated with survivin in a compassionate use setting despite the fact that strong CTL responses were introduced in all patients [54]. Nevertheless, it is clear that even extensive phase I/II trials are not really suited for analyses of potential side effect presenting several years after termination of the trial, and clearly these issues demands further attention.

With the fast through-put technologies developed over the past decade [13, 45], our insight into the molecular events that lead to malignant phenotype have reached another level of understanding. Obviously, characterization of new markers or patterns set the stage for the specific targeting of cancer cells by the development of new therapies, which in turn can be combined with strategies that take advantage of the targeting capacity of the immune system. The crucial point is to focus on structures that combines current knowledge not only in the field of cancer biology per se, but also includes the interplay between current conventional treatment strategies and how this influences the malignant cell population and the immune system. Without any doubt, although a large number of antigens have been characterized to date it appears that we have nonetheless only revealed the tip of the iceberg. However, future efforts should focus on antigens or 
groups of antigens that conceptually incorporate biological and clinical knowledge.

\section{Conclusions}

In conclusion, the synergistic effects of conventional and immunological therapies necessitate re-thinking of the clinical strategies not only with respect to the chosen chemotherapeutics, but also considering design of the selected immunotherapy. In this respect, targeting of proteins or patterns that are important for survival and growth of cancer cells seems to be promising as a universal anti-tumor vaccine, which synergistically boosts the effects of conventional cytotoxic therapies.

Open Access This article is distributed under the terms of the Creative Commons Attribution Noncommercial License which permits any noncommercial use, distribution, and reproduction in any medium, provided the original author(s) and source are credited.

\section{References}

1. Andersen MH, Becker JC, thor Straten P (2005) Regulators of apoptosis: suitable targets for immune therapy of cancer. Nat Rev Drug Discov 4:399-409

2. Andersen MH, Keikavoussi P, Bröcker EB, Schuler-Thurner B, Jonassen M, Søndergaard I, thor Straten P, Becker JC, Kämpgen E (2001) Induction of systemic CTL responses in melanoma patients after dendritic cell vaccination: correlation between disease progression and cessation of CTL responses. Int J Cancer 61:820 824

3. Andersen MH, Kvistborg P, Becker JC, thor Straten P (2005) Identification of an HLA-A1 restricted CTL epitope from Mcl-1. Leukemia 19:1084-1085

4. Andersen MH, Ostergaard Pedersen L, Becker JC, thor Straten P (2001) Identification of a cytotoxic T lymphocyte response to the apoptose inhibitor protein survivin in cancer patients. Cancer Res 61:869-872

5. Andersen MH, Reker S, Becker JC, thor Straten P (2004) The melanoma inhibitor of apoptosis protein ML-IAP: a target for spontaneous cytotoxic T-cell responses. J Invest Dermatol 122:392-399

6. Andersen MH, Reker S, Kvistborg P, Becker JC, thor Straten P (2005) Spontaneous immunity against Bcl-Xl in cancer patients. J Immunol 175:2709-2714

7. Andersen MH, Soerensen RB, Becker JC, thor Straten P (2006) HLA-A24 and survivin: possibilities in therapeutic vaccination against cancer. J Transl Med 4:38

8. Andersen MH, Svane IM, Kvistborg P, Juul Nielsen O, Balslev E, Reker S, Becker JC, thor Straten P (2005) Immunogenicity of Bcl2 in cancer patients. Blood 105:728-734

9. Aptsiauri N, Cabrera T, Garcia-Lora A, Lopez-Nevot MA, RuizCabello F, Garrido F (2007) MHC class I antigens and immune surveillance in transformed cells. Int Rev Cytol 256:139-189

10. Berger C, Jensen MC, Lansdorp PM, Gough M, Elliott C, Riddell SR (2008) Adoptive transfer of effector CD8 T cells derived from central memory cells establishes persistent $\mathrm{T}$ cell memory in primates. J Clin Invest 118:294-305

11. Bredel M (2001) Anticancer drug resistance in primary human brain tumors. Brain Res Brain Res Rev 35:161-204
12. Britten CM, Gouttefangeas C, Welters MJ, Pawelec G, Koch S, Ottensmeier C, Mander A, Walter S, Paschen A, Muller-Berghaus J, Haas I, Mackensen A, Kollgaard T, thor Straten P, Schmitt M, Giannopoulos K, Maier R, Veelken H, Bertinetti C, Konur A, Huber C, Stevanovic S, Wolfel T, van der Burg SH (2007) The CIMT-monitoring panel: a two-step approach to harmonize the enumeration of antigen-specific CD8(+) T lymphocytes by structural and functional assays. Cancer Immunol Immunother 57:289302 (E-pub ahead of print)

13. Celis JE, Moreira JM, Gromova I, Cabezon T, Ralfkiaer U, Guldberg P, thor Straten P, Mouridsen H, Friis E, Holm D, Rank F, Gromov P (2005) Towards discovery-driven translational research in breast cancer. FEBS J 272:2-15

14. Chidgey A, Dudakov J, Seach N, Boyd R (2007) Impact of niche aging on thymic regeneration and immune reconstitution. Semin Immunol 19:331-340

15. Cobbold M, Khan N, Pourgheysari B, Tauro S, McDonald D, Osman H, Assenmacher M, Billingham L, Steward C, Crawley C, Olavarria E, Goldman J, Chakraverty R, Mahendra P, Craddock C, Moss PA (2005) Adoptive transfer of cytomegalovirus-specific CTL to stem cell transplant patients after selection by HLA-peptide tetramers. J Exp Med 202:379-386

16. Colombo MP, Piconese S (2007) Regulatory-T-cell inhibition versus depletion: the right choice in cancer immunotherapy. Nat Rev Cancer 7:880-887

17. Cullen SP, Martin SJ (2007) Mechanisms of granule-dependent killing. Cell Death Differ 15:251-262

18. de Visser KE, Eichten A, Coussens LM (2006) Paradoxical roles of the immune system during cancer development. Nat Rev Cancer 6:24-37

19. del Rio ML, Penuelas-Rivas G, Dominguez-Perles R, Ramirez P, Parrilla P, Rodriguez-Barbosa JI (2005) Antibody-mediated signaling through PD-1 costimulates T cells and enhances CD28dependent proliferation. Eur J Immunol 35:3545-3560

20. Dias S, Shmelkov SV, Lam G, Rafii S (2002) VEGF(165) promotes survival of leukemic cells by Hsp90-mediated induction of Bcl-2 expression and apoptosis inhibition. Blood 99:2532-2540

21. Dranoff G (2005) CTLA-4 blockade: unveiling immune regulation. J Clin Oncol 23:662-664

22. Dudley ME, Rosenberg SA (2007) Adoptive cell transfer therapy. Semin Oncol 34:524-531

23. Eggert AA, Schreurs MW, Boerman OC, Oyen WJ, de Boer AJ, Punt CJ, Figdor CG, Adema GJ (1999) Biodistribution and vaccine efficiency of murine dendritic cells are dependent on the route of administration. Cancer Res 59:3340-3345

24. Filipazzi P, Valenti R, Huber V, Pilla L, Canese P, Iero M, Castelli C, Mariani L, Parmiani G, Rivoltini L (2007) Identification of a new subset of myeloid suppressor cells in peripheral blood of melanoma patients with modulation by a granulocyte-macrophage colony-stimulation factor-based antitumor vaccine. J Clin Oncol 25:2546-2553

25. Folkman J (2007) Angiogenesis: an organizing principle for drug discovery? Nat Rev Drug Discov 6:273-286

26. Gabrilovich DI (2007) Combination of chemotherapy and immunotherapy for cancer: a paradigm revisited. Lancet Oncol 8:2-3

27. Gabrilovich DI, Ishida T, Nadaf S, Ohm JE, Carbone DP (1999) Antibodies to vascular endothelial growth factor enhance the efficacy of cancer immunotherapy by improving endogenous dendritic cell function. Clin Cancer Res 5:2963-2970

28. Gallina G, Dolcetti L, Serafini P, De SC, Marigo I, Colombo MP, Basso G, Brombacher F, Borrello I, Zanovello P, Bicciato S, Bronte V (2006) Tumors induce a subset of inflammatory monocytes with immunosuppressive activity on $\mathrm{CD} 8+\mathrm{T}$ cells. $\mathrm{J}$ Clin Invest 116:2777-2790

29. Ghiringhelli F, Menard C, Puig PE, Ladoire S, Roux S, Martin F, Solary E, Le Cesne A, Zitvogel L, Chauffert B (2007) Metronomic 
cyclophosphamide regimen selectively depletes CD4+CD25+ regulatory $\mathrm{T}$ cells and restores $\mathrm{T}$ and NK effector functions in end stage cancer patients. Cancer Immunol Immunother 56:641-648

30. Grossman D, Altieri DC (2001) Drug resistance in melanoma: mechanisms, apoptosis, and new potential therapeutic targets. Cancer Metastasis Rev 20:3-11

31. Hanahan D, Weinberg RA (2000) The hallmarks of cancer. Cell 100:57-70

32. Helmbach H, Rossmann E, Kern MA, Schadendorf D (2001) Drug-resistance in human melanoma. Int J Cancer 93:617-622

33. Hillen F, Griffioen AW (2007) Tumour vascularization: sprouting angiogenesis and beyond. Cancer Metastasis Rev 26:489-502

34. Idenoue S, Hirohashi Y, Torigoe T, Sato Y, Tamura Y, Hariu H, Yamamoto M, Kurotaki T, Tsuruma T, Asanuma H, Kanaseki T, Ikeda H, Kashiwagi K, Okazaki M, Sasaki K, Sato T, Ohmura T, Hata F, Yamaguchi K, Hirata K, Sato N (2005) A potent immunogenic general cancer vaccine that targets survivin, an inhibitor of apoptosis proteins. Clin Cancer Res 11:1474-1482

35. Jaattela M (2004) Multiple cell death pathways as regulators of tumour initiation and progression. Oncogene 23:2746-2756

36. Janetzki S, Panageas KS, Ben-Porat L, Boyer J, Britten CM, Clay TM, Kalos M, Maecker HT, Romero P, Yuan J, Martin KW, Hoos A (2007) Results and harmonization guidelines from two largescale international Elispot proficiency panels conducted by the Cancer Vaccine Consortium (CVC/SVI). Cancer Immunol Immunother 57:303-315

37. Kashkar H, Seeger JM, Hombach A, Deggerich A, Yazdanpanah B, Utermohlen O, Heimlich G, Abken H, Kronke M (2006) XIAP targeting sensitizes Hodgkin lymphoma cells for cytolytic T-cell attack. Blood 108:3434-3440

38. Kavanagh B, Ko A, Venook A, Margolin K, Zeh H, Lotze M, Schillinger B, Liu W, Lu Y, Mitsky P, Schilling M, Bercovici N, Loudovaris M, Guillermo R, Lee SM, Bender J, Mills B, Fong L (2007) Vaccination of metastatic colorectal cancer patients with matured dendritic cells loaded with multiple major histocompatibility complex class I peptides. J Immunother (1997) 30:762-772

39. Lissoni P, Malugani F, Bonfanti A, Bucovec R, Secondino S, Brivio F, Ferrari-Bravo A, Ferrante R, Vigore L, Rovelli F, Mandala M, Viviani S, Fumagalli L, Gardani GS (2001) Abnormally enhanced blood concentrations of vascular endothelial growth factor (VEGF) in metastatic cancer patients and their relation to circulating dendritic cells, IL-12 and endothelin-1. J Biol Regul Homeost Agents 15:140-144

40. Lotze MT, Zeh HJ, Rubartelli A, Sparvero LJ, Amoscato AA, Washburn NR, Devera ME, Liang X, Tor M, Billiar T (2007) The grateful dead: damage-associated molecular pattern molecules and reduction/oxidation regulate immunity. Immunol Rev 220:60-81

41. Maecker B, Sherr DH, Vonderheide RH, Bergwelt-Baildon MS, Hirano N, Anderson KS, Xia Z, Butler MO, Wucherpfennig KW, O'Hara C, Cole G, Kwak SS, Ramstedt U, Tomlinson AJ, Chicz RM, Nadler LM, Schultze JL (2003) The shared tumor-associated antigen cytochrome P450 1B1 is recognized by specific cytotoxic T cells. Blood 102:3287-3294

42. Matsuda M, Petersson M, Lenkei R, Taupin JL, Magnusson I, Mellstedt H, Anderson P, Kiessling R (1995) Alterations in the signal-transducing molecules of T cells and NK cells in colorectal tumor-infiltrating, gut mucosal and peripheral lymphocytes: correlation with the stage of the disease. Int J Cancer 61:765-772

43. McFadyen MC, McLeod HL, Jackson FC, Melvin WT, Doehmer J, Murray GI (2001) Cytochrome P450 CYP1B1 protein expression: a novel mechanism of anticancer drug resistance. Biochem Pharmacol 62:207-212

44. Meier A, Reker S, Svane IM, Holten-Andersen L, Becker JC, Søndergaard I, Andersen MH, thor Straten P (2005) Spontaneous CTL responses against peptides derived from the taxol resistance associated gene-3 (Trag-3) protein in cancer patients. Cancer Immunol Immunother 54:219-228

45. Monsurro V, Marincola FM (2007) Gene profiling for the prediction of tumor response to treatment: the case of immunotherapy. Adv Exp Med Biol 593:86-94

46. Monsurro V, Nagorsen D, Wang E, Provenzano M, Dudley ME, Rosenberg SA, Marincola FM (2002) Functional heterogeneity of vaccine-induced CD8(+) T cells. J Immunol 168:5933-5942

47. Monsurro V, Wang E, Panelli MC, Nagorsen D, Jin P, Katia Z, Smith K, Ngalame Y, Even J, Marincola FM (2003) Active-specific immunization against melanoma: is the problem at the receiving end? Semin Cancer Biol 13:473-480

48. Monsurro V, Wang E, Yamano Y, Migueles SA, Panelli MC, Smith K, Nagorsen D, Connors M, Jacobson S, Marincola FM (2004) Quiescent phenotype of tumor-specific CD8+ T cells following immunization. Blood 104:1970-1978

49. Morgan RA, Dudley ME, Wunderlich JR, Hughes MS, Yang JC, Sherry RM, Royal RE, Topalian SL, Kammula US, Restifo NP, Zheng Z, Nahvi A, de Vries CR, Rogers-Freezer LJ, Mavroukakis SA, Rosenberg SA (2006) Cancer regression in patients after transfer of genetically engineered lymphocytes. Science 314:126129

50. Niethammer AG, Xiang R, Becker JC, Wodrich H, Pertl U, Karsten G, Lemishka TI, Reisfeld RA (2002) The vascular endothelial growth factor receptor 2: a self-antigen recognized by cytotoxic T cells mediating tumor-protective immunity. Nat Med 8:13691375

51. North RJ (1982) Cyclophosphamide-facilitated adoptive immunotherapy of an established tumor depends on elimination of tumorinduced suppressor T cells. J Exp Med 155:1063-1074

52. Obeid M, Tesniere A, Ghiringhelli F, Fimia GM, Apetoh L, Perfettini JL, Castedo M, Mignot G, Panaretakis T, Casares N, Metivier D, Larochette N, Van EP, Ciccosanti F, Piacentini M, Zitvogel L, Kroemer G (2007) Calreticulin exposure dictates the immunogenicity of cancer cell death. Nat Med 13:54-61

53. Ohnmacht GA, Marincola FM (2000) Heterogeneity in expression of human leukocyte antigens and melanoma-associated antigens in advanced melanoma. J Cell Physiol 182:332-338

54. Otto K, Andersen MH, Eggert AA, Keikavoussi P, Ostergaard Pedersen L, Rath JC, Bock M, Brocker E, thor Straten P, Kampgen E, Becker JC (2004) Therapy-induced T cell responses against the universal tumor antigen survivin. Vaccine 23:884-889

55. Parmiani G, Castelli C, Dalerba P, Mortarini R, Rivoltini L, Marincola FM, Anichini A (2002) Cancer immunotherapy with peptide-based vaccines: what have we achieved? Where are we going? J Natl Cancer Inst 94:805-818

56. Pawelec G, Heinzel S, Kiessling R, Muller L, Ouyang Q, Zeuthen J (2000) Escape mechanisms in tumor immunity: a year 2000 update. Crit Rev Oncog 11:97-133

57. Rapoport AP, Stadtmauer EA, Aqui N, Badros A, Cotte J, Chrisley L, Veloso E, Zheng Z, Westphal S, Mair R, Chi N, Ratterree B, Pochran MF, Natt S, Hinkle J, Sickles C, Sohal A, Ruehle K, Lynch C, Zhang L, Porter DL, Luger S, Guo C, Fang HB, Blackwelder W, Hankey K, Mann D, Edelman R, Frasch C, Levine BL, Cross A, June CH (2005) Restoration of immunity in lymphopenic individuals with cancer by vaccination and adoptive T-cell transfer. Nat Med 11:1230-1237

58. Rochat B, Morsman JM, Murray GI, Figg WD, McLeod HL (2001) Human CYP1B1 and anticancer agent metabolism: mechanism for tumor-specific drug inactivation? J Pharmacol Exp Ther 296:537-541

59. Ropke M, Hald J, Guldberg P, Zeuthen J, Norgaard L, Fugger L, Svejgaard A, van der Burg SH, Nijman HW, Melief CJM, Claesson M-H (1996) Spontaneous human squamous cell carcinomas are killed by a human cytotoxic $\mathrm{T}$ lymphocyte clone recognizing a 
wild-type p53-derived peptide. Proc Natl Acad Sci USA 93:14704-14707

60. Sakaguchi S (2005) Naturally arising Foxp3-expressing CD25+CD4+ regulatory T cells in immunological tolerance to self and non-self. Nat Immunol 6:345-352

61. Sallusto F, Geginat J, Lanzavecchia A (2004) Central memory and effector memory $\mathrm{T}$ cell subsets: function, generation, and maintenance. Annu Rev Immunol 22:745-763

62. Sallusto F, Mackay CR (2004) Chemoattractants and their receptors in homeostasis and inflammation. Curr Opin Immunol $16: 724-731$

63. Schmidt H, Suciu S, Punt CJ, Gore M, Kruit W, Patel P, Lienard D, von der Maase H, Eggermont AM, Keilholz U (2007) Pretreatment levels of peripheral neutrophils and leukocytes as independent predictors of overall survival in patients with American Joint Committee on Cancer Stage IV Melanoma: results of the EORTC 18951 Biochemotherapy Trial. J Clin Oncol 25:1562-1569

64. Schmitz M, Diestelkoetter P, Weigle B, Schmachtenberg F, Stevanovic S, Ockert D, Rammensee HG, Rieber EP (2000) Generation of survivin-specific CD8+ T effector cells by dendritic cells pulsed with protein or selected peptides. Cancer Res 60:4845-4849

65. Schultze JL, Vonderheide RH (2001) From cancer genomics to cancer immunotherapy: toward second-generation tumor antigens. Trends Immunol 22:516-523

66. Schumacher TN (2002) T-cell-receptor gene therapy. Nat Rev Immunol 2:512-519

67. Seliger B, Ritz U, Ferrone S (2006) Molecular mechanisms of HLA class I antigen abnormalities following viral infection and transformation. Int J Cancer 118:129-138

68. Shangary S, Johnson DE (2003) Recent advances in the development of anticancer agents targeting cell death inhibitors in the Bcl2 protein family. Leukemia 17:1470-1481

69. Slingluff CL Jr, Cox AL, Henderson RA, Hunt DF, Engelhard VH (1993) Recognition of human melanoma cells by HLA-A2.1-restricted cytotoxic T lymphocytes is mediated by at least six shared peptide epitopes. J Immunol 150:2955-2963

70. Slingluff CL Jr, Speiser DE (2005) Progress and controversies in developing cancer vaccines. J Transl Med 3:18

71. Sommerfeldt N, Beckhove P, Ge Y, Schutz F, Choi C, Bucur M, Domschke C, Sohn C, Schneeweis A, Rom J, Pollmann D, Leucht D, Vlodavsky I, Schirrmacher V (2006) Heparanase: a new metastasis-associated antigen recognized in breast cancer patients by spontaneously induced memory $\mathrm{T}$ lymphocytes. Cancer Res 66:7716-7723

72. Tanaka K, Iwamoto S, Gon G, Nohara T, Iwamoto M, Tanigawa N (2000) Expression of survivin and its relationship to loss of apoptosis in breast carcinomas. Clin Cancer Res 6:127-134
73. Tsuruma T, Hata F, Torigoe T, Furuhata T, Idenoue S, Kurotaki T, Yamamoto M, Yagihashi A, Ohmura T, Yamaguchi K, Katsuramaki T, Yasoshima T, Sasaki K, Mizushima Y, Minamida H, Kimura H, Akiyama M, Hirohashi Y, Asanuma H, Tamura Y, Shimozawa K, Sato N, Hirata K (2004) Phase I clinical study of anti-apoptosis protein, survivin-derived peptide vaccine therapy for patients with advanced or recurrent colorectal cancer. J Transl Med 2:19

74. Vonderheide RH, Hahn WC, Schultze JL, Nadler LM (1999) The telomerase catalytic subunit is a widely expressed tumor-associated antigen recognized by cytotoxic $\mathrm{T}$ lymphocytes. Immunity 10:673-679

75. Vukmanovic-Stejic M, Zhang Y, Cook JE, Fletcher JM, McQuaid A, Masters JE, Rustin MH, Taams LS, Beverley PC, Macallan DC, Akbar AN (2006) Human CD4+ CD25hi Foxp3+ regulatory T cells are derived by rapid turnover of memory populations in vivo. J Clin Invest 116:2423-2433

76. Wacheck V, Selzer E, Gunsberg P, Lucas T, Meyer H, Thallinger C, Monia BP, Jansen B (2003) Bcl-x(L) antisense oligonucleotides radiosensitise colon cancer cells. Br J Cancer 89:1352-1357

77. Wang S, Yang D, Lippman ME (2003) Targeting Bcl-2 and Bcl$\mathrm{XL}$ with nonpeptidic small-molecule antagonists. Semin Oncol 30:133-142

78. Wendel HG, Lowe SW (2004) Reversing drug resistance in vivo. Cell Cycle 3:847-849

79. Whiteside TL (1999) Signaling defects in T lymphocytes of patients with malignancy (see comments). Cancer Immunol Immunother 48:346-352

80. Wing K, Fehervari Z, Sakaguchi S (2006) Emerging possibilities in the development and function of regulatory T cells. Int Immunol 18:991-1000

81. Xiang R, Mizutani N, Luo Y, Chiodoni C, Zhou H, Mizutani M, Ba Y, Becker JC, Reisfeld RA (2005) A DNA vaccine targeting survivin combines apoptosis with suppression of angiogenesis in lung tumor eradication. Cancer Res 65:553-561

82. Yamada A, Kawano K, Koga M, Matsumoto T, Itoh K (2001) Multidrug resistance-associated protein 3 is a tumor rejection antigen recognized by HLA-A2402-restricted cytotoxic T lymphocytes. Cancer Res 61:6459-6466

83. Zhang B, Maris CH, Foell J, Whitmire J, Niu L, Song J, Kwon BS, Vella AT, Ahmed R, Jacob J, Mittler RS (2007) Immune suppression or enhancement by CD137 T cell costimulation during acute viral infection is time dependent. J Clin Invest 117:3029-3041

84. Zhou H, Luo Y, Mizutani M, Mizutani N, Reisfeld RA, Xiang R (2005) T cell-mediated suppression of angiogenesis results in tumor protective immunity. Blood 106:2026-2032 